\title{
Critical Analysis on Enforcing the sincerity exploration as a requirement in giving the Mining Business Permit (Licence)
}

\author{
Dewi Cahy andari \\ Faculty of Law \\ Brawijaya University \\ Malang, Indonesia \\ dewicahy andari@ub.ac.id
}

\author{
Sudarsono \\ Faculty of Law \\ Brawijaya University \\ Malang, Indonesia \\ sudarsono@ub.ac.id
}

\begin{abstract}
Discussion related to mining is a discussion with never ended topic. Almost all countries in the world compete to dominate natural resources like oil, natural gas, gold, coal, etc. Countries with the biggest natural oil resource will attract the investors; therefore, the role to give licence (permit) becomes something important to control exploitations towards the earth which might cause the environment to get damages. The existence of the mining business licence (permit) holders to give money as "sincerity exploration warranty" has actually been arranged in the regulation of protection and Environment management. It is due to the regulation no. 322009 that states the Environment Protection and Management manages the warranty fund. Since there is warranty requirement related to the 'sincerity exploration', it makes the mining business permit management become overlapping. The aims of this artide are that the writers want to try to criticize the form of the regulation related to giving the sincerity exploration permit and to give recommendations for those who make (design) the regulations to manage the management of giving the mining business permit well.
\end{abstract}

\section{Keywords - mining, licence, environment}

\section{INTRODUCTION}

Mining world is not a new topic to discuss any more. Furthermore, some researchers stated that the human civilization was signed with the mining development. We can take an example that in the old era people used to use stones and ceramics gotten from digging the soil to make their daily equip ment. There are also mining in Egypt which becomes the widest mining in the area of Nubia. In the Roman era, there was a silver mining in Laurium. In the medieval century, mining industry developed drastically because the mining industry focused on the chopper and metal extraction in which those two kinds of mine were used to make the weapons, battle equipment, and armors.

In the modern era, the mining area has developed to a much better condition, both from the exploration and its technology as well. Good news comes from Indonesia, based on the survey done by the United State Geology Survey; Indonesia occupies the sixth biggest mining owners. In 2015 the Indonesian Mining Industry values reach US\$ 147 billion. Meanwhile, in the Southeast Asia, Indonesia occupies the highest position for new mining projects that are going to be done, followed by Philippine and Vietnam.
In 2017 the Indonesian income from the mining sector reached 18.269.673.300.937[1]

Indonesia position has already taken strategic place with the wealth from the mining result; it attracts the investors to invest their shares in Indonesia. We can see the data from the ESDM Ministry; the holders of the Mining Business Service Permit in Indonesia I 2011 - 2015 have increased[1] (2011 : 351. 2012: 475. 2013: 578, $2014: 445$, 2015 :629). Seeing the data given by the ESDM Ministry, we can indicate that mining business in Indonesia is still alive and can develop well.

The resource governance index institute 2017 (NRGI) rated that the governance on the mining sector in Indonesia occupied the eleventh position among 89 special assessment in the country level sector, and it occupies the second position after India in the Southeast Asia. In the index that assesses the state governance, Indonesia got 68 points from 100 points; this achievement was based on the Indonesia Government openness in the budget, the income and the state expenditures, the profit sharing fund in the region levels, and the expenditure adjustment during the last two years. It indicates that the oil and gas governance in Indonesia has reached to betterment. Therefore, it can increase the trust in the mining investors.

However, bad things come from the mining sector permit. Natural Resource Governance Institute (NRGI) takes note that the mining sector permit got 37 points from 100 points that became the measurements. There is not openness in the financial interest towards the public done by the officials, the real identity from the real owners and the contracts as well. As we all know that the permit is the control given by the government to protect Indonesian sovereignty from the forbidden stuffs; however, the bad management in handling the mining sector permit makes the mining sectoritself weak.

In this article, the writers also highlight some requirements in handling the mining permit which seems overlapping. There are some requirements that must be fulfilled in handling the mining business permit. The regulation no. 42009 states that "minerals and coal mining as the legal protection towards the mining management in Indonesia mentions that business mining permit is a permit to do the mining business'. In case of handling the business, 
mining permit means that the business mining permits on exploration mining, the exploration business mining permit is a business permit given to do some steps of general exploration investigation and feasibility study.

In the requirements of business exploration mining permit proposal in article 39 verse (1) letter (d) Regulation no. 42009 about the Mineral and Coal Mining, there is a requirement to give 'sincerity warranty' that has meaning that the sincerity warranty is not explained more details in this regulation; however, the sincerity warranty includes the cost of the environ ment management due to the effect of the exploration activities ${ }^{1}$. Related to the sincerity warranty in the Regulation no. 322009 about the protection and the environment management, it manages the similar warranty money. It relates to the sincerity warranty that also exists in the government regulations. It can increase the complexity in the permit management in the mining sector, especially in the financial requirement.

\section{DISCUSSION}

The overlapping regulations that manage something are not a new topic. Related to the sincerity warranty management in handling the business mining exploration permit, we need to pay attention to some regulations that manage them. Article 39 number 1 letter $d$ requires the proposal to handle the business mining exploration permit must fulfill 'sincerity warranty'. There is no definition related to the sincerity warranty in these regulations; however, the sincerity warranty in the explanation includes the cost to manage the environment that affects the exploration activities. In the regulation of Energy and Mineral Resource Minister no. 342017 about the permit in Mineral and coal sector (as the implementation regulations related to the management of the business mining permit) there is no conceptual definition about 'the sincerity warranty'; however, in the article 8 number (3) it is stated that the exploration sincerity warranty meant in verse (2) is placed in the form of a long term deposit that is put in the government bank or regional government on behalf of the General Director or the Governor qq the applicant IUP Exploration or IUPK Exploration with some requirements (conditions). By using Grammatical Approach Method, the writers can conclude that the sincerity warranty is money that must be deposited to the government as a warranty form that the applicants ask the permission to do the mining business well and can do the environment rehabilitation after the mining exploration business is done. Talking about the environment rehabilitation, we cannot keep our views away from the Regulation no. 322009 about the protection and the management of the environ ment. This regulation is a legal protection that relates very much with the environment protection. In this regulation there is also similar case, in article 43 number (2) letter (a) it is stated that the instrument funding is suitable with article 42 letter $b$ that covers 'environment rehabilitation warranty fund'. The warranty fund must be given to the environment holders. As we all know in the Administrative Law, a permit is an instrument that can be used by the authorized government officials to manage how the businessmen run their businesses [2]. Based on the Regulation no. 322009 about the Protection and the Environment Management, the environment Permit is given

\footnotetext{
${ }^{1}$ Mining business permits are divided into exploration mining business
} permit s and operation mining business permits. for the activity categories that can cause the environment pollution or environment destruction ${ }^{2}$. We still take the same base, in the same Regulation, we can conclude some matters, the first is that the environment permit is passed on the business activities which must be "Amdal" (Environ ment Effect Analysis) or UKL-UPL because Amdal and UKL-UPL is passed on the activities which throw the waste or the activities that take the natural resources; therefore, it means that the environment permit is passed on the activities that can cause the environment pollution or environment destruction. If we refer to provision in Regulation no 42009 about mineral and coal, it is stated that the purpose of the warranty fund is to protect the environment damages after the exploration mining business; it means that the management related to the environment rehabilitation after the activity done is based on the permit released by the government officials which is managed in some regulations namely Regulation no 42009 about Minerals and Coal and also the regulation no. 322009 about the Protection and the Environment Management. Due to those problems and based on the regulation theory, we can analyze some matters. Basically the forming of the regulation regulations is the forming of the legal norms that is applied outside and has general characteristics with wide meaning. The regulation rules are the written decisions done by the country or the government which have instructions or behavior patterns with binding characters in general[3]. The scope of the regulation in the material meaning (wet in materiele zin) is usually called algemeen verbindende voorschrifften which is as a decision from the authorized organs to make the regulation regulations; therefore, the content of the regulations are binding in general, cannot be applied to certain individual events, more precisely it is something binding generally than binding the public[4].

If a conflict happens to norms that belong to the regulation, there is a principle that can become a solution for those regulation conflicts. In the preference principle, we know the principle of lex superior derogat legi inferiori, which means that the higher regulations put the lower regulations aside, the principle of lex specialis derogat legi generali, which means that the special regulations put the general regulations aside; the principle of lex posteriori derogat legi priori, it means that the new regulations put the old regulations aside. In the application the principle of lex posteriori derogat legi priori means that the regulation no. 322009 about the Protection and Environ ment Management puts aside the regulation no 42009 about Mineral and Coal. There is a norm conflict inside.

Lon Fuler gave 8 guidances (benchmarks) to explain about the legal certainty. A law system that consists of some regulations is not based on a moment decision for certain matters; those regulations are announced to public; they are applied backwards, because it can destroy the system integrity; it is made in the formulas that are understood by public; there should not be regulations that are contradict to one another; it is not allowed to sue an action that can be done more than it is supposed to be; it is not allowed to change something often; there must be suitability between the regulations and the daily applications. If we see the guidances (benchmarks) given by Lon Fuller, we can say that there are some points that cannot be fulfilled by the

\footnotetext{
2 Article 1 number 35 of Law number 32 of 2009 about environmental
} protection and management 
regulation makers (designers) to manage "the sincerity Warranty", namely there is a formula that cannot be understood by the public; moreover, there is regulation that manages the same things so that it does not guarantee the law certainty inside. On the other hand according to Sudargo Gautama the legal Certainty is the form of the legality principle that can be seen from two sides namely from the citizen sides, as the continuation from the principles of the state authority limitation towards individual which is considered a violation towards the individual rights and they can be done if we are allowed to do so based on the legal regulations. From the state (nation) side, every nation's action must be based on the law. The regulation rules that are applied (held) first are the limits of the nation's actions [5]. We should consider that the legal certainty is a legal protection warranty given by the nation towards the citizens, therefore; when there is an uncertainty in the regulation related to "sincerity warranty" that must be paid by the applicants to the government, it means that the applicants do not get the legal uncertainty so that there is no legal protection for the applicants upon the costs they have paid.

Principally in designing (making) the regulations, the government must fulfill some principles (besides the material principles stated in the Regulation no 122011 about Designing (Making) The Regulation Rules), they must also have principles in the law/legal areas that are managed in the regulations themselves [6] In this case the principles in the permit law must be obeyed by the regulation designer (maker).

\section{CONCLUSION}

Regulation is one of laws in Indonesia. When there is a problem in the regulation rules, there are some implications that can happen due to it. The first, there is no legal certainty for the permit applicants upon "the sincerity warranty" that must be paid, it is because there are two regulations
(Regulation no 42009 about The Mineral and the Coal and the regulation no 322009 about the Protection and the Environment Management) that manage the same matters. The second, from the uncertainty that appears upon the regulation about "the sincerity Warranty", it can create an injustice for the applicants who propose the business mining permit.

Regulations related to "the sincerity warranty" are still chaotic (awful). It is because there are two regulations that manage the same matters. Preference Principles have not answered those problems yet. Suggestions (feedback) for the regulation designers (makers) are expected to understand more about the regulation related to "sincerity warranty". And to be able to manage again those regulations well. Considering Indonesia is a country that is seen by many mining investors in the world. The regulations about issuing the permit need to be repaired, it is because a good permit mining governance can create confidence from the investors to Indonesian government.

\section{REFERENCES}

[1] "MINERBA Statistic, year 2017." [Online]. Available: https://www.minerba.esdm.go.id/library/content/file/28935-Minerba dalam angka/a5b4050c90717fb4bbc591c0ef5c38472017-09-20-1806-31.pdf.

[2] T. Rahmadi, Hukum Lingkungan di Indonesi. Depok: Rajawali Press, 2015.

[3] B. Manan, Dasar-Dasar Konstitusional Peraturan PerundangUndangan Nasional. Padang: Fakultas Hukum, Universitas Andalas, 1994.

[4] A. Dakhoir, "Konstruksi Hukum Pengaturan Kelembagaan Pengelolaan Zakat Terintegrasi Dalam Fungsi Sosial Perbankan Syariah," Brawijaya University, 2014.

[5] S. Gautama, Pengertian tentang Negara Hukum. Yogyakarta: Liberty, 1973.

[6] J. Asshidiqie, Perihal Undang-Undang. Depok: Rajawali Press, 2010 